\title{
The Impact of Extensive and Intensive Focus on Form Strategies on EFL Learners' Oral Accuracy
}

\author{
Massoud Rahimpour \\ Department of Foreign Languages and Literature, University of Tabriz, Tabriz, Iran \\ E-mail: Rahimpour2011@gmail.com \\ Asghar Salimi (Corresponding author) \\ Faculty of Humanities, University of Maragheh, Maragheh, Iran \\ E-mail: Asgharsalimi356@gmail.com \\ Farahman Farrokhi \\ Department of Foreign Languages and Literature, University of Tabriz, Tabriz, Iran \\ E-mail: ffarrokhi20@yahoo.co.uk
}

Received: 11-07- 2012

Accepted: 30-07- 2012

Published: 01-11- 2012

doi:10.7575/ijalel.v.1n.6p.37

URL: http://dx.doi.org/10.7575/ijalel.v.1n.6p.37

\begin{abstract}
One of the most controversial issues in applied linguistics over the past two decades concerns the role of conscious and unconscious processes in second language learning. On the other hand, many researchers believe that focusing on the target language system is necessary if learners are to produce language forms. However, what remains missing in the literature of focus on form is the effect of the degree of noticing and attention (intensive/extensive) on EFL learners' oral/written production. Thus, the main purpose of the present study is to investigate the effect of intensive and extensive focus on form on EFL learners' oral production. To this end, 40 learners of English at pre-intermediate level were chosen randomly as the participants of the study and assigned into two groups of intensive and extensive. They received 20 sessions of intensive and extensive form-focused instructions. A narrative task and a delayed focused and unfocused task were employed to collect data from the participants. The collected oral data was quantified in terms of the accuracy measure. Independent Samples T-test was employed as the statistical means of analysis. The results of the study revealed no differences between the performances of two groups in terms of the accuracy in oral narrative task. However, the result of statistical analysis for the delayed post-test in focused intensive task was significant. The study might carry some pedagogical implications for second language teachers, SLA researchers, teacher education and task designers.
\end{abstract}

Keywords: Consciousness and noticing, intensive focus on form, extensive focus on form, focus on forms, accuracy

\section{Introduction}

One of the most controversial issues in applied linguistics since the past two decades concerns the role of conscious and unconscious processes in second language learning. On the other hand, many researchers believe that focusing on the target language (TL) system is necessary if learners are to produce language forms (Bialystock, 1979; Schmidt, 1994, 2001; Ellis, 2003, 2008). Pourhosseini and Ahmadi (2011) also argue that consciousness is a core in second language acquisition (SLA) and its role in SLA is of considerable importance and should specifically be considered if we are to make progress in understanding how acquisition of SL takes place. The main purpose of the present experimental study is to investigate the effects of intensive and extensive focus on form strategies on L2 learners' oral accuracy in English as a Foreign Language (EFL) context.

\section{Literature Review}

Focus on form has been one of the hotly debated issues in Second Language Acquisition (SLA) over the past two decades. Mastering the grammar of a second/foreign language and being able to correctly implement this knowledge is a demanding and challenging task to accomplish, which is the reason for many English as a Second Language (ESL) students to find it difficult to express themselves accurately in speech or writing. Furthermore, the mastery over linguistic elements as an element of pragmatic competence in language learning, and the 
complex nature of SL pragmatic development presents learners of English as a second language and their classroom instructors with significant challenges. Taking these challenges into account, (including instruction) that may contribute to this development is a worthwhile goal. In the context of classroom instruction, several studies suggest that explicit instruction promotes development (Ellis, 1999, 2003, 2004, 2005, 2008; Rahimpour, 2001; Rahimpour and Salimi, 2010; Farrokhi and Rahimpour, 2011; Rahimpour and Maghsoudpour, 2011). This instruction can be implanted within Task-Based Language Teaching (TBLT) as focus on form.

Norris and Ortega (2000) examined the effectiveness of L2 instruction by conducting a meta-analysis of experimental or quasi-experimental studies suggesting that explicit instruction is superior to implicit instruction and they provide evidences for the durability of instruction. They argue that " a focus on form and a focus on forms are equally effective" (p. 5011). The distinction between these two approaches refers to the fact that the syllabus, the nature of attention to form, and the primary focus of attention on many of forms are different. As Doughty (2001) argues:

The factor that distinguishes focus on form from other pedagogical approaches is the requirement that focus on form involves learners' briefly and perhaps simultaneously attending to form, meaning, and use during one cognitive event (p. 211).

Long (1983) defines focus on form as “focus on form... actually draws learner's attention to linguistic elements, as they arise incidentally in lessons whose overwriting focus is on meaning or communication (p.456)".

Focus on forms according to Long is defined as traditional teaching approach in which teacher presents learners with pre-selected and sequenced linguistic items. Schmidt (1994, 2001) also argues that L2 learner must efficiently notice and be aware of the features of input in order for intake and learning to be possible. Corrective feedback and form-focused instruction has attracted the attention of many SLA searchers. Although the proponents of naturalistic SL acquisition believe that CF is not only useless but also harmful because it disrupts the flow of discourse of communication, there are many researchers who claim that CF is effective and necessary and has a facilitative role in SL development (Schimdt, 1990; Rahimpour, 2001; Long, 1990, 1996; Swain, 1998). These researchers claim that noticing involved in focus on form helps learners to notice the gap between foreign/target language. Van Patten (2002) and Ellis (2009) support the role of focus on form in the form of negotiation for meaning in making the learner notice their errors and creating form-meaning connections.

Some studies have been carried out on the effectiveness of corrective feedback in form of focus on form on L2 learners' accuracy. Rahimpour and Maghsoudpour (2011) studied the effect of form-focused instruction and task-based instruction on L2 learners' interaction and language development. The results of the study revealed that FFI group outperformed TBI group in terms of interaction. Hejazi (2012) also studied the effect of teachers' error correction on 95 Iranian EFL learners' speech accuracy. The result of the study proved significant differences between the error correction and L2 learners" accuracy in EFL context. Fahim and Hashemnejad (2011) also studied the effect of mixed pattern vs. separate pattern of providing corrective feedback on EFL learners' accuracy. They concluded that the coded feedback was much more effective than simple error location. Farahani and Sarkhosh (2012) studied the effect of different types of textual input enhancement on 114 EFL learners' intake of English subjunctive mood. The results of the study proved the effectiveness of intensive underlining textual enhancement format in inducing the intake of target structure, i.e. input enhancement was effective when it was intensive. Khatib and Bagherkazemi (2011) studied the effect of learners' output on enhancing EFL learners' short-term and long-term learning of simple present tense. The results of the study revealed a trend toward significance within three weeks of experimental period. The results showed clear benefit arising from pushing students to produce SL output for the short-term and long-term learning of simple present tense. However, offering more output opportunities over time might be the key factor to the efficiency of learner output in the acquisition of the target language forms. In line with the findings of this study, one can argue that intensive, repeated and frequent drawing of learners' attention to linguistic forms might lead to more accuracy. Chu (2011) also found significant difference between teacher's error correction and Chinese L2 learners' of English in terms of oral accuracy. However, what remains missing in the literature of focus on form is the effect of the degree of noticing and attention (intensive/extensive) on EFL learners' oral production and the effect of the degree of attention and noticing on foreign language learners' accuracy (Ellis, 2008). Based on Schmidt's (1990, 2001) Noticing Hypothesis and instructed second language acquisition principles (Ellis, 2008), it could be argued that intensive/focused focus on form strategy would lead to more accuracy than extensive/unfocused one. Extensive focus on form, according to Ellis (2003), is defined as drawing learners' attention on the whole range of linguistic items involving various grammatical, lexical, and phonological non-target like forms produced by 
the learner. Intensive focus on form, however, involves drawing learners' attention represented by items, particularly a grammatical one. This area of research can contribute to different aspects of language pedagogy. Thus, the main purpose of the present study is to investigate the effect of intensive and extensive focus on form on EFL learners' oral production.

\section{Methodology}

\subsection{Research question and hypothesis}

This study aims at addressing the following research question and hypotheses:

$R Q$ : What are the effects of intensive and extensive focus on form on EFL learners' oral accuracy?

H0: There is not any significant difference between extensive and intensive focus on form instruction and L2 learners' oral accuracy.

H1: Learners' receiving intensive focus on form instruction will outperform learners who receive extensive focus on form instruction.

\subsection{Participants}

The participants of the study were 40 pre-intermediate female learners of English affiliated to Iran National Language Institute in West Azerbaijan, Miandoab, Iran. They were chosen randomly and divided into 2 groups of extensive and intensive instruction on the basis of their performance on Oxford Proficiency Test (OPT) (2004).

\subsection{Procedure}

One group of learners received extensive correct feedback in the form recast on their erroneous utterances within communication on range of grammatical, phonological and lexical errors, while the intensive group received feedback from the teacher for the pre-selected language forms which was past tense. They received instruction for one semester (20 sessions). Oral narrative picture prompt which meets the criteria of task introduced by Ellis (2003) was used as a means of data collection and the collected data was measured in terms of accuracy measure. A written production test designed by the researcher and two other experts in the field of language teaching and testing was also used as a delayed post-test to see the effectiveness and durability of each type of instruction.

\section{Data analysis and results}

The quantified data of orally reordered data were fed into SPSS software (Version 16). T-test was employed as the statistical means of analysis for comparing the means of 2 groups in narrative task, as well as the delayed post-test.

Table1. shows the result of descriptive statistical for the comparing means of intensive and extensive groups

\begin{tabular}{lcccc}
\hline & $\mathrm{N}$ & Mean & Std. Deviation & Std. Error Mean \\
\hline Extensive oral task accuracy & 20 & 0.49 & 0.16512 & 0.03692 \\
Intensive oral task accuracy & 20 & 0.53 & 0.11743 & 0.02626 \\
\hline
\end{tabular}

Table 1 shows the result of descriptive statistics for the accuracy of intensive and extensive groups in oral task. According to the table, intensive group produced more accurate oral language than the extensive group.

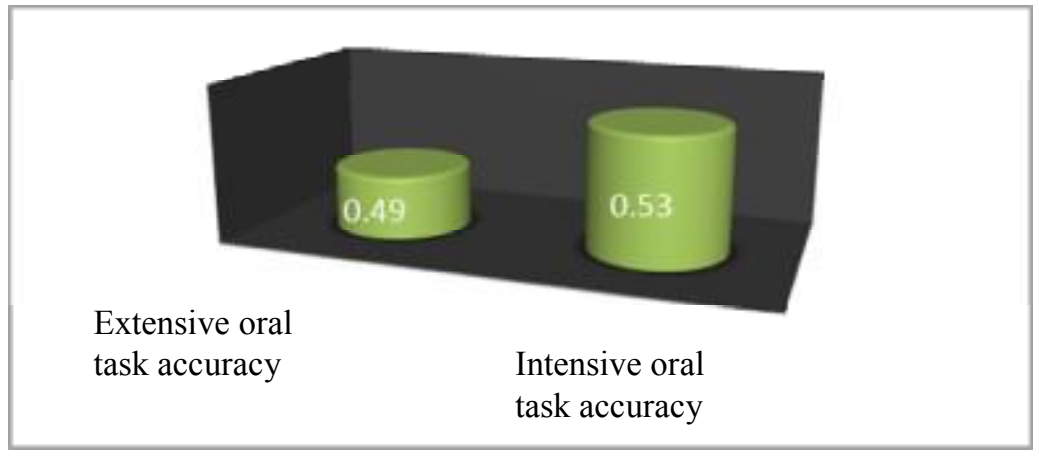

Figure 1. shows the mean differences of 2 groups' accuracy on oral narrative task. 
International Journal of Applied Linguistics \& English Literature

ISSN 2200-3592 (Print), ISSN 2200-3452 (Online)

Vol. 1 No. 6; November 2012

Independent Samples T-test was employed as the statistical means of analysis for comparing means of two groups.

Table 2. Independent Samples T-test for the means of intensive and extensive groups

\begin{tabular}{|c|c|c|c|c|c|c|c|c|c|}
\hline & \multicolumn{2}{|c|}{$\begin{array}{c}\text { Levene's Test } \\
\text { for Equality of } \\
\text { Variances }\end{array}$} & \multirow{3}{*}{$\mathrm{t}$} & \multirow{3}{*}{$\mathrm{df}$} & \multicolumn{3}{|c|}{ T-test for Equality of Means } & & \\
\hline & $\mathrm{F}$ & Sig. & & & \multirow[t]{2}{*}{$\begin{array}{c}\text { Sig. } \\
\text { (2-tailed) }\end{array}$} & \multirow[t]{2}{*}{$\begin{array}{c}\text { Mean } \\
\text { Difference }\end{array}$} & \multirow[t]{2}{*}{$\begin{array}{l}\text { Std. Error } \\
\text { Difference }\end{array}$} & \multicolumn{2}{|c|}{$\begin{array}{c}\text { 95\% Confidence } \\
\text { Interval of the } \\
\text { Difference }\end{array}$} \\
\hline & & & & & & & & Lower & Upper \\
\hline $\begin{array}{l}\text { Equal variances } \\
\text { assumed }\end{array}$ & 1.992 & 0.166 & -0.883 & 38 & 0.383 & -0.04 & 0.04531 & -0.13172 & 0.05172 \\
\hline $\begin{array}{l}\text { Equal variances } \\
\text { not assumed }\end{array}$ & & & -0.883 & 34.305 & 0.383 & -0.04 & 0.04531 & -0.13204 & 0.05204 \\
\hline
\end{tabular}

According to this table, there was no significant difference between the accuracy of two groups on oral task. The above table shows the results very vividly

In order to test the effect of the durability of instruction on L2 learners' accuracy, a delayed post-test including two written production tasks namely intensive/planned and extensive/unplanned were employed.

Table 3. Descriptive statistics for the accuracy of delayed post-test in focused task

\begin{tabular}{lcccc}
\hline Grouping & $\mathrm{N}$ & Mean & Std. Deviation & $\begin{array}{c}\text { Std. Error } \\
\text { Mean }\end{array}$ \\
\hline $\begin{array}{l}\text { Accuracy Intensive } \\
\text { Focused }\end{array}$ & 20 & 14.35 & 1.725 & .386 \\
$\begin{array}{l}\text { Accuracy Extensive } \\
\text { Focused }\end{array}$ & 20 & 12.55 & 2.012 & .450 \\
\hline
\end{tabular}

Table 3 shows the results of descriptive statistics for the accuracy of delayed focused task.

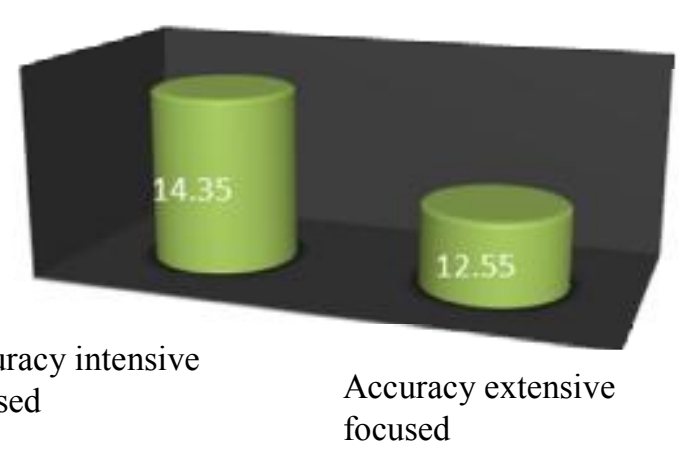

Figure 2. Comparison of the means of accuracy of delayed post-test in focused task

Figure 2 also shows the means of accuracy in focused task for both groups. It is clear that participants receiving intensive form-focused instruction outperformed extensive group in terms of accuracy in delayed post-test focused task. 
International Journal of Applied Linguistics \& English Literature

ISSN 2200-3592 (Print), ISSN 2200-3452 (Online)

Vol. 1 No. 6; November 2012

Table 4. Independent Samples T-test for the accuracy of delayed post-test in focused task

\begin{tabular}{|c|c|c|c|c|c|c|c|c|c|}
\hline & \multicolumn{2}{|c|}{$\begin{array}{l}\text { Levene's Test } \\
\text { for Equality } \\
\text { of Variances }\end{array}$} & \multirow{3}{*}{$\mathrm{t}$} & \multirow{3}{*}{ df } & \multicolumn{3}{|c|}{ T-test for Equality of Means } & \multirow{2}{*}{\multicolumn{2}{|c|}{$\begin{array}{c}95 \% \text { Confidence } \\
\text { Interval of the } \\
\text { Difference }\end{array}$}} \\
\hline & $\mathrm{F}$ & Sig. & & & \multirow[t]{2}{*}{$\begin{array}{l}\text { Sig. } \\
\text { (2-tail } \\
\text { ed) }\end{array}$} & \multirow[t]{2}{*}{$\begin{array}{c}\text { Mean } \\
\text { Difference }\end{array}$} & \multirow[t]{2}{*}{$\begin{array}{l}\text { Std. Error } \\
\text { Difference }\end{array}$} & & \\
\hline & & & & & & & & Lower & Upper \\
\hline $\begin{array}{l}\text { Equal } \\
\text { variances } \\
\text { assumed }\end{array}$ & .467 & .499 & 2.793 & 37 & .008 & 1.613 & .578 & .443 & 2.783 \\
\hline $\begin{array}{l}\text { Equal } \\
\text { variances not } \\
\text { assumed }\end{array}$ & & & 2.787 & $\begin{array}{c}36.30 \\
2\end{array}$ & .008 & 1.613 & .579 & .440 & 2.787 \\
\hline
\end{tabular}

Table 4 shows the results of Independent Samples T-test for the accuracy of delayed post-test in focused task for both groups. The results of statistical analysis show that there is significant difference between means of two groups in terms of the accuracy in focused task. As a result, intensive form-focused instruction was much more effective and durable than intensive form-focused instruction in the delayed post-test. Thus, our null hypothesis is rejected and the hypothesis stating that "learners receiving intensive focus on form strategies will outperform learners receiving extensive focus on form in terms of accuracy" is confirmed.

Table 5. Descriptive statistics for the accuracy of delayed post-test in unfocused task

\begin{tabular}{lccc}
\hline & Mean & Std. Deviation & $\mathrm{N}$ \\
\hline Accuracy Intensive Unfocused & 12.40 & 1.569 & 20 \\
Accuracy Extensive Unfocused & 13.35 & 1.663 & 20 \\
\hline
\end{tabular}

Table 5 shows the descriptive statistics of groups in intensive and extensive in terms of accuracy in unfocused task in the delayed post-test.

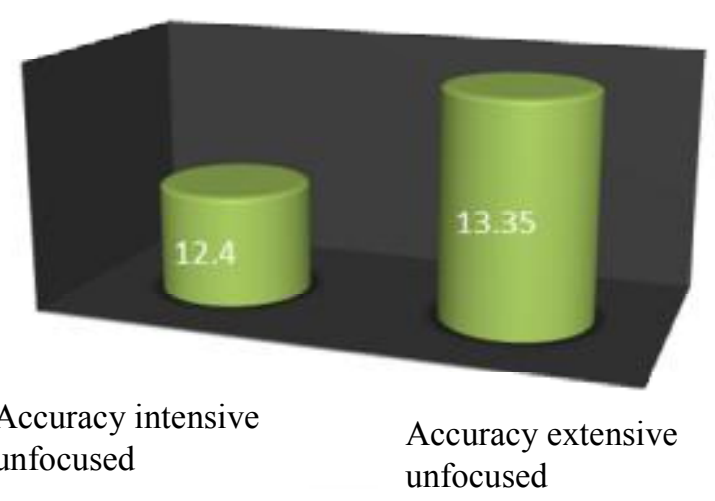

Figure 3. Comparison of the means of accuracy of delayed post-test in unfocused task

Figure 3 shows that learners receiving extensive form-focused instruction outperformed learners receiving intensive form-focused instruction in terms of accuracy in unfocused task in the delayed post-test. 
International Journal of Applied Linguistics \& English Literature

ISSN 2200-3592 (Print), ISSN 2200-3452 (Online)

Vol. 1 No. 6; November 2012

Table 6. Independent Samples T-test for the accuracy of written production unfocused task in intensive and extensive FOF groups

\begin{tabular}{|c|c|c|c|c|c|c|c|c|c|}
\hline & \multicolumn{2}{|c|}{$\begin{array}{c}\text { Levene's Test } \\
\text { for Equality } \\
\text { of Variances }\end{array}$} & \multirow{3}{*}{$\mathrm{t}$} & \multirow{3}{*}{ df } & \multicolumn{3}{|c|}{ T-test for Equality of Means } & & \\
\hline & $\mathrm{F}$ & Sig. & & & $\begin{array}{c}\text { Sig. } \\
\text { (2-tailed) }\end{array}$ & $\begin{array}{c}\text { Mean } \\
\text { Difference }\end{array}$ & $\begin{array}{l}\text { Std. Error } \\
\text { Difference }\end{array}$ & \multicolumn{2}{|c|}{$\begin{array}{l}95 \% \text { Confidence } \\
\text { Interval of the } \\
\text { Difference }\end{array}$} \\
\hline & & & & & & & & Lower & Upper \\
\hline $\begin{array}{l}\text { Equal variances } \\
\text { assumed }\end{array}$ & .101 & .752 & -1.858 & 38 & .071 & -.950 & .511 & -1.985 & .085 \\
\hline $\begin{array}{l}\text { Equal variances } \\
\text { not assumed }\end{array}$ & & & -1.858 & 37.873 & .071 & -.950 & .511 & -1.985 & .085 \\
\hline
\end{tabular}

According to table 6, no significant difference was found between the performances of two groups in delayed post-test in unfocused task in delayed post-test. As a result, the null hypothesis stating that "there is not any significant difference between intensive and extensive focus on form and L2 learners' accuracy" is confirmed.

\section{Discussion}

Considering the results of statistical analysis for the effect of intensive and extensive focus on form on L2 learners' oral accuracy in oral narrative task, it was revealed that the two groups' performance was not statistically significant, although the mean of accuracy of intensive group was higher than extensive one. The findings of the study are in line with Fahim and Hashemzadeh (2011) who found that providing feedback on mixed patterns vs. separate patterns is much more effective. However, the findings of the study ran against the studies like Farahani and Sarkhosh (2012), Hejazi (2012), and Khatib and Bagherkazenmi (2012) who found that intensive form-focused instruction was more effective than extensive one. They agreed that drawing learners' attention repeatedly to the same linguistic feature would lead to more accuracy. However, the findings of these researchers (Farahani and Sarkhosh, 2012; Hejazi , 2012; Khatib and Bagherkazenmi, 2012; Chu, 2011) are in line with the results of our study in the delayed post-test. This high rate in accuracy can be attributed to the fact that the more frequent, repeated, and intensive the focus on form, the deeper the processing of target language feature takes place.

Like every other experimental study, this study has also some limitations. First, individual differences and their possible effects on L2 learners' performance was not taken into account in this study. Second, this study took into account the past form reference as the form under focus. The study could be replicated with other language forms, tasks with other genres than narrative, and individual learner differences.

\section{Pedagogical implications}

This study has some pedagogical implications for language teachers and educators, SLA researcher, as well as task and syllabus designers. Language teachers and educators need to consider ways of involving students more fully in the process of using feedback in order to enhance its potential benefits (Hyland, 2010). Teachers should help students to develop practices of feedback use which will scaffold and engage them as they develop their own self monitoring capabilities. Some level of consciousness is necessary for SLA. Consciousness provides an opportunity to unite useful concept from cognitive psychology. This point should be taken into account by SLA researchers to relate feedback to SLA theories. Accuracy is as important as fluency and complexity for appropriate communication. Task designers should consider some role for focus on form in designing task specifically in EFL contexts. Teacher training programs could also work to raise teachers' awareness of the different feedback sources and modes of delivery available to them and possible ways of combining them to make an effective support system.

\section{References}

Bialystock, E. (1979). Explicit and implicit judgment of L2 grammaticality. Language Learning, 29(1), 81-103. Chu, R. (2011). Effects of teacher's corrective feedback on accuracy in the oral English of English-majors College students. Theory and Practice in Language Studies, 1(5), 454-459.

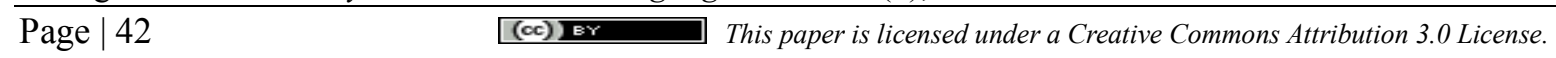


International Journal of Applied Linguistics \& English Literature

ISSN 2200-3592 (Print), ISSN 2200-3452 (Online)

Vol. 1 No. 6; November 2012

Ellis, R. (1994). The study of second language acquisition. Oxford, England: Oxford University Press.

Ellis, R (1999). Input-based approaches to teaching grammar: A review of classroom-oriented research. Annual Review of Applied Linguistics, 19, 64-80.

Ellis, R. (2001). Investigating form-focused instruction. In R. Ellis (Ed.), Form-focused instruction and second language learning (pp. 1-46). Malden, MA: Black well publishers.

Ellis, R. (2003). Task-based language learning and teaching. Oxford, England: Oxford University Press.

Ellis, R (Ed.) (2005). Planning and task performance in a second language. Amsterdam: John Benjamins .

Ellis, R. (2008). Typology of written corrective feedback. ELT Journal; doi: 10. 1093/elt/ccn023.

Ellis, R. (2009). Task-based language teaching: Sorting out the misunderstandings. International Journal of Applied Linguistics, 19(3), pp. 229-246.

Doughty, C. (2001). Cognitive underpinning of focus on form. In. P. Robinson (Eds.). Cognition and Second Language Acquisition, (pp. 206-257). Cambridge: CUP.

Fahim, M. \& Hashemnejad, H. (2011). Corrective feedback provision: Mixed pattern vs. separate pattern. Theory and Practice in Language Studies, 1(8), 1019-1024.

Farahani, A. K. \& Sarkhosh, M. (2012). Do different textual enhancement formats have different effects on the intake of English subjunctive mood? Theory and Practice in Language Studies, 2(4), 688-698.

Farrokhi, F. \& Rahimpour, M. and Papi, Z. (2011). Incidental focus on form techniques in Iranian EFL

classroom: A comparison between expert and novice teachers. English Language Teaching, 1(1), 150-157.

Hejazi, M. (2012). Teacher's error correction: A key factor in developing Iranian EFL learners' speech accuracy. Theory and Practice in Language Studies, 2(3), 619-624.

Hyland, F. (2010). Future directions in feedback on second language writing: Overview and research agenda. International Journal of English Studies. 10(2), 171-182.

Khatib, M. \& Bagherkazemi, M. (2011). The potential of learner output for enhancing EFL learners' short-term and long-term learning of the English simple present tense. Theory and Practice in Language Studies, 1 (4), 400-407.

Long, M.H., (1983). Does second language instruction make a difference? A review of the research. TESOL Quarterly, 17(3), 359-382.

Long, M.H., (1990). Maturational constraints on language development. Studies in Second Language

Acquisition, 12, 251-285.

Long, M. H. (1996). The role of linguistic environment in second language acquisition. In W.C.Ritchie\&

T.K.Bhatia (Eds.). Handbook of second language acquisition. (pp.413-463). San Diego; Academic Press.

Noris, J. M., \& Ortega, L. (2000). Effectiveness of L2 instruction: A research synthesis and quantitative meta-analysis. Language Learning, 50, 417-528.

Pourhossein, A. \& Ahmadi, S. M. (2011). Role of consciousness in SLA. Theory and Practice in Language Studies, 1(5), 435-442.

Rahimpour, M. (2001). The acquisition of L2 in instructed and naturalistic situation. Journal of Faculty of Letters and Humanities. University of Tabriz, 44, 10-39.

Rahimpour, M. \& Maghsoudpour, M. (2011). Teacher-students' interactions in task-based vs. form-focused instruction. World Journal of Education, 1(1), 171-178.

Rahimpour, M. \& Salimi, A. (2010). The impact of explicit instruction on foreign language learners' performance. Procedia-Social and Behavioral Sciences, 2, 1740-1746.

Salimi, A., Dadashpour, S., Asadollahfam, H. (2011). The effect of task complexity on EFl learners' written performance. Procedia- Social and Behavioral Sciences, 29, 1390-1399.

Schmidt, R. (1990). The role of consciousness in second language learning. Applied Linguistics, 11, 129-158.

Schmidt, R. (1994). "Implicit Learning and the cognitive unconscious: of artificial grammars and SLA". In N.C. Ellis (Ed.), Implicit and explicit learning of Languages (pp. 165-209). San Diego, CA: Academic Press.

Schmidt, R. (2001). Attention, In P. Robinson (Ed.), Cognition and second Language instruction (pp. 3-32).

Cambridge: Cambridge University Press.

Swain, M. (1998). 'Focus on form through conscious reflection' in C. Doughty \& J. Williams (Eds.), pp: 64-81. Van Patten, B. (2002). Processing instruction: An update. Language Learning, 52, 755-803. 